\title{
Promazine Hydrochloride
}

National Cancer Institute

\section{Source}

National Cancer Institute. Promazine Hydrochloride. NCI Thesaurus. Code C47691.

The hydrochloride salt form of promazine, a phenothiazine derivative with antipsychotic and antiemetic properties. Promazine hydrochloride blocks postsynaptic dopamine receptors D1 and D2 in the mesolimbic and medullary chemoreceptor trigger zone (CTZ), thereby decreasing stimulation of the vomiting center in the brain and psychotic effects, such as hallucinations and delusions. In addition, this agent blocks alphaadrenergic receptors and exhibits strong anticholinergic activity. 